\title{
Znaczenie przywództwa kooperatywnego w Unii Europejskiej w świetle teorii neoliberalnego instytucjonalizmu
}

\author{
The Importance of Cooperative Leadership in the European Union \\ in the Light of the Theory of Neoliberal Institutionalism
}

\section{- Abstrakt •}

Model przywództwa kooperatywnego jest rozwiązaniem alternatywnym wobec przywództwa rozumianego w kategoriach dominacji, hegemonii czy narzucania własnej woli politycznej pozostałym podmiotom uczestniczącym w układzie wzajemnych powiązań. Specyfika systemu politycznego Unii Europejskiej nadaje duże znaczenie zarówno mechanizmom międzyrządowym, jak i ponadnarodowym, natomiast kluczową rolę w kształtowaniu tego systemu nadal odgrywają państwa członkowskie. Mimo że postanowienia traktatowe zagwarantowały formalną równość państw, znaczenie Niemiec jako nieformalnego lidera Wspólnoty staje się coraz częściej przedmiotem politycznej debaty o UE. Uwzględniając założenia neoliberalnego instytucjonalizmu związane zarówno z kluczową pozycją państw, jak i dużym znaczeniem instytucji gwarantujących przejrzystość ich działań, a także biorąc pod uwagę długotrwałe korzyści ze współpracy, w artykule zdefiniowano pojęcie przywództwa w kontekście zachowań kooperacyjnych państwa. Przyjęte ramy metodologicz-

\section{- Abstract}

The model of cooperative leadership is an alternative solution to leadership understood in terms of domination, hegemony or imposing its own political will on other entities participating in the system of mutual connections. The specificity of the political system of the European Union gives great importance to both intergovernmental and supranational mechanisms, while the key role in shaping this system is still played by the Member States. Although the treaty provisions ensured formal equality of states, the importance of Germany as an informal leader of the Community is increasingly becoming the subject of political debate about the EU. Taking into account the assumptions of neoliberal institutionalism related to both the key position of states and the great importance of institutions guaranteeing the transparency of their activities, as well as taking into account the long-term benefits of cooperation, the article defines the concept of leadership in the context of state cooperative behavior. The adopted methodological and theoretical framework allo- 
no-teoretyczne pozwoliły na szczegółową analizę wpływu Niemiec w UE, zwłaszcza na polu działań dyplomatycznych.

Celem artykułu było określenie głównych wyznaczników roli Niemiec jako lidera UE, który swoje przewodnictwo opiera na współpracy z innymi państwami członkowskimi, uznając i respektując rozwiązania instytucjonalne, które ograniczają możliwość realizacji indywidualnych priorytetów i gwarantują przejrzystość działań na rzecz wspólnych interesów, a w dłuższej perspektywie legitymizują rolę państwa jako nieformalnego lidera, który reprezentuje wynegocjowane na forum instytucji wspólne stanowisko. Wykorzystując metodę instytucjonalno-prawną, metodę badań zastanych oraz studium przypadku (negocjacje pokojowe w ramach formatu normandzkiego), zweryfikowano główne założenia i potwierdzono, że wyznacznikiem przywództwa Niemiec jest nie tylko potencjał polityczny i gospodarczy, ale także zdolność do współpracy i dostarczanie informacji instytucjom UE na temat działań w zakresie realizacji priorytetów Wspólnej Polityki Zagranicznej i Bezpieczeństwa. Podejście oparte na respektowaniu wspólnych interesów i przejrzystości działań wzmocniło wizerunek Niemiec jako lidera UE.

Słowa kluczowe: współpraca międzynarodowa; neoliberalny instytucjonalizm; dyplomacja europejska; Wspólna Polityka Zagraniczna i Bezpieczeństwa; przywództwo kooperatywne wed for a detailed analysis of Germany's influence in the EU, especially in the field of diplomatic activities.

The aim of the article was to define the main determinants of the role of Germany as the EU leader, which bases its leadership on cooperation with other Member States, recognizing and respecting institutional solutions that limit the possibility of implementing individual priorities and guarantee transparency of actions for common interests, and in the long run legitimize the role of the state as an informal leader who represents a common position negotiated in the forum of the institutions. Using the institutional and legal method, the method of existing research and a case study (peace negotiations under the Normandy format), the main assumptions were verified and it was confirmed that the determinant of Germany's leadership is not only its political and economic potential, but also the ability to cooperate and provide information to $\mathrm{EU}$ institutions on activities in the implementation of the priorities of the Common Foreign and Security Policy. The approach based on respect for common interests and transparency of actions strengthened Germany's image as a leader.

Keywords: international cooperation; neoliberal institutionalism; European diplomacy; Common Foreign and Security Policy; cooperative leadership

\section{Uwagi wstępne}

Potrzeba kooperacji we współczesnym, zglobalizowanym świecie wynika ze struktury relacji międzynarodowych. Państwa funkcjonujące w coraz bardziej złożonym środowisku, w którym występuje wiele zagrożeń i liczne kontakty między społeczeństwami, muszą nieustannie adaptować się do nowych zmian zachodzących w dynamicznym otoczeniu politycznych, gospodarczych i społeczno-kulturowych interakcji. W związku z tym stają przed coraz większymi ograniczeniami w samodzielnym wykonywaniu podstawowych zadań. Ze względu na skalę lub charakter wielu problemów państwa często nie są w stanie rozwiązać ich bez współpracy z in- 
nymi podmiotami, dlatego tworzą koalicje zarówno w ramach minilateralnych formatów, jak i wielostronnych sieci powiązań. Wyjaśnia to coraz bardziej powszechny paradygmat przywództwa kooperatywnego, które zakłada współpracę i podział obowiązków między wszystkich uczestników biorących udział w tworzeniu określonych struktur. Rola lidera jest przy tym znacząca, gdyż odpowiada on za koordynację pracy grupy, ale nie jest to przywództwo rozumiane w kategorii hegemonii i narzucania własnej woli politycznej innym państwom.

W artykule skoncentrowano się na kluczowych założeniach neoliberalnego instytucjonalizmu: znaczeniu międzynarodowej współpracy, kluczowej pozycji państwa jako podmiotu tej współpracy oraz instytucjach, dzięki którym rozwijana współpraca może być skuteczna. $\mathrm{Na}$ ich podstawie zdefiniowano główne determinanty modelu przywództwa kooperatywnego. Przyjęcie takiej perspektywy badawczej z jednej strony pozwala na identyfikację wpływu państwa na określone zinstytucjonalizowane struktury formalne, a z drugiej strony na wyjaśnienie znaczenia instytucji jako centralnego punktu koordynującego wspólne stanowiska. Wykorzystując te założenia teoretyczne oraz metody: instytucjonalno-prawną i badań zastanych, przeanalizowano znaczenie kooperacji państw członkowskich, przede wszystkim Niemiec i Francji, z uwzględnieniem wpływu, jaki mają w UE. Badania Coalition Explorer oraz ranking wpływu państw członkowskich z 2020 r. potwierdzają potencjał współpracy Niemiec i Francji jako najbardziej wpływowych państw UE. Ich sojusz, mimo że nie może samodzielnie kształtować polityk unijnych, ma istotny wpływ na określanie kierunku integracji oraz Wspólnej Polityki Zagranicznej i Bezpieczeństwa. Zgodnie z głównym założeniem przywództwo w UE nie może być rozpatrywane w kategorii przywództwa indywidualnego Niemiec, ale raczej w ramach przywództwa kooperatywnego, które zakłada, że wpływ państwa uzależniony jest od potencjału trwałych koalicji, jakie tworzy w ramach poszczególnych inicjatyw. Rolę lidera odgrywa państwo o znaczącym potencjale politycznym lub gospodarczym, które jest w stanie przyjąć odpowiedzialność za wytyczanie kierunku grupie i zarządzanie działaniami w celu realizacji wspólnie określonych priorytetów (Zawadzka, 2020, s. 80-102). Celem artykułu jest identyfikacja i wyjaśnienie przesłanek postrzegania Niemiec jako państwa, które swoją przywódczą rolę w UE opiera na kooperacji, szczególnie z Francją jako swoim głównym koalicjantem. Przykładem wdrożenia modelu przywództwa kooperatywnego w celu realizacji priorytetów Wspólnej Polityki Zagranicznej i Bezpieczeństwa były negocjacje w ramach formatu normandzkiego, gdzie Niemcy i Francja reprezentowały stanowisko zgodne $\mathrm{z}$ konsultowanym $\mathrm{w}$ ramach struktur instytucjonalnych UE, co przyczyniło się do legitymizacji ich czołowej roli w dyplomacji europejskiej. 


\section{Współpraca międzynarodowa w świetle teorii neoliberalnego instytucjonalizmu}

Przedstawiciele neoliberalnego instytucjonalizmu, podobnie jak zwolennicy neorealizmu, uznają anarchiczną strukturę stosunków międzynarodowych za główną determinantę zachowań podmiotów polityki globalnej, z których najważniejsza pozycja przypisywana jest także państwom narodowym, które kierują się racjonalną kalkulacją własnych interesów (Kozub-Karkut, 2015, s. 71-72). Zasadnicza sprzeczność na poziomie analizy porównawczej neoliberalnego instytucjonalizmu i neorealizmu dotyczy przede wszystkim roli instytucji międzynarodowych, natury i konsekwencji anarchicznej struktury relacji międzynarodowych, współpracy między państwami, a także względnych i absolutnych korzyści. W kontekście analizy zagadnienia przywództwa kooperatywnego najbardziej uzasadnione jest omówienie sprzeczności w definiowaniu determinantów i szans współpracy międzynarodowej.

Neorealiści zdecydowanie większą wagę przywiązują w swych rozważaniach do kwestii bezpieczeństwa, natomiast neoliberalni instytucjonaliści za jeden z kluczowych determinantów współzależności na arenie międzynarodowej uznają kwestie gospodarcze, które definiują ich potencjał oraz konieczność współpracy. Według Roberta Keohane i Josepha Nye, głównych przedstawicieli neoliberalnego instytucjonalizmu, współzależność gospodarcza jest kluczową cechą polityki światowej, w której dominującymi podmiotami są państwa. Wzrost wzajemnych powiązań oraz ich instytucjonalizacja wpływają na kształtowanie się pozytywnych wzorców zachowań i nowych sposobów kooperacji, która minimalizuje konsekwencje anarchicznej struktury relacji międzynarodowych (Keohane, Nye, 2001). Według realistów współpraca między państwami jest utrudniona ze względu na naturalną chęć rywalizacji i maksymalizacji własnych korzyści. Zachowanie aktorów na scenie międzynarodowej jest nieprzewidywalne, dlatego granice współpracy wyznacza chęć przetrwania i rywalizacji. Neorealiści częściej będą poddawać analizie przywództwo indywidualne zorientowane na dominację i narzucanie woli politycznej.

Kenneth Waltz, jeden z kluczowych przedstawicieli realizmu strukturalnego, stwierdził, że państwa, które stają w obliczu możliwości współpracy w imię wspólnych interesów, muszą uwzględnić to, w jaki sposób korzyści z danych działań zostaną podzielone. Realiści zapytają nie o to, „czy oboje zyskamy?”, ale o to, „kto zyska więcej?” (Waltz, 1990 za: Kegley, 2008, s. 30). Inne podejście do współpracy międzynarodowej reprezentują przedstawiciele neoliberalnego instytucjonalizmu, którzy w swoich analizach w większym stopniu koncentrują się na korzyściach, jakie odnosi państwo, niż na aspekcie dominacji korzyści własnych nad korzyścia- 
mi innych stron. Decydenci zgodnie z takim podejściem powinni koncentrować się na korzyściach bezwzględnych wynikających z porozumienia, w tym na korzyściach długoterminowych, a nie na krótkoterminowym zysku. Neoliberalny instytucjonalizm uwzględnia działanie państw we własnym interesie, ale jednocześnie z dużym optymizmem odnosi się do zjawiska trwałej kooperacji, która mimo że może prowadzić do różnych napięć, to jednocześnie przynosi istotne korzyści państwom (Whyte, 2020). Osiągnięcie zysków ze współpracy jest z kolei możliwe dzięki instytucjom, które zapewniają mechanizm koordynacyjny - „skonstruowany punkt centralny" dla lepszej koordynacji wspólnych działań i jednocześnie zapewniają przejrzystą platformę dostarczającą informacji, które utrudniają oszukiwanie i czerpanie większych korzyści kosztem pozostałych stron (Keohane, Martin, 1995, s. 45). Mimo że neoliberalny instytucjonalizm przyjmuje realistyczne założenie, zgodnie z którym państwa funkcjonują w anarchicznym systemie, kierując się własnymi interesami, to uwzględnia istotną rolę instytucji, które koordynują strategie kooperacyjne i usuwają element niepewności, dostarczając informacji na temat potencjału i zakresu działania stron (Keohane, Martin, 1995, s. 43). Neorealizm i neoliberalny instytucjonalizm pomimo wielu różnic łączą niektóre kryteria analityczne. Przede wszystkim oba paradygmaty mają charakter państwocentryczny. Państwa są podstawowymi jednostkami analizy, a kluczowe zagadnienie, jakiego dotyczy owa analiza, wyjaśnia i uzasadnia specyfikę zachowania państw w odniesieniu do materialnej struktury systemu międzynarodowego (Thomas, 2001, s. 10). Oba podejścia teoretyczne uznają międzynarodową anarchię za determinantę przyszłej polityki w wymiarze globalnym, jednak neorealiści znacznie wyolbrzymiają jej znaczenie kosztem współzależności, która jest kluczowa w ujęciu neoliberalnego instytucjonalizmu, gdyż wyjaśnia potrzebę kooperacji podmiotów państwowych w celu uzyskania wzajemnych korzyści i minimalizowania w dłuższej perspektywie negatywnych konsekwencji anarchicznej struktury relacji (Baldwin, 1993, s. 4). Mimo że współpraca w takich uwarunkowaniach jest trudna, ponieważ anarchia uskutecznia możliwość odstąpienia od przyjętych porozumień, to tworzenie międzynarodowych instytucji umożliwia wprowadzenie mechanizmów dystrybucji informacji, które niwelują problem nieprzestrzegania prawa, sankcjonując niezgodności w działaniach państw (Keohane, 1984, s. 89-90). Istnienie stabilnych instytucji sprawia, że państwa mniej martwią się o to, kto zyskuje więcej, a z większą uwagą odnoszą się do korzyści bezwzględnych ze współpracy. Dla neorealistów, którzy traktują zapewnienie bezpieczeństwa jako nadrzędny cel państwa, najważniejszym czynnikiem wpływającym na jego realizację jest ogólny rozkład zdolności i potencjału w porównaniu z możliwościami innych państw. Względna wielkość potencjału i zdolności są kluczowe z uwagi na nieprzewidywalność za- 
chowań pozostałych podmiotów. Zatem rozkład zdolności w systemie globalnym determinuje postrzeganie przez państwa własnych interesów narodowych (Waltz, 1979, s. 105; Grieco, 1990, s. 39-45). Dla każdego państwa jego siła w odniesieniu do potencjału innych państw ma stanowić o jego przetrwaniu w anarchicznym systemie międzynarodowym (Waltz, 1954, s. 210). Z kolei według neoliberalnych instytucjonalistów interesy państwa są związane nie tylko z rozkładem zdolności, ale również z funkcjonowaniem instytucji międzynarodowych, które wpływają na oczekiwania wobec zachowań innych państw.

Procedury, obowiązujące normy oraz informacje, jakich dostarczają instytucje, zmniejszają koszty współpracy, a działanie samodzielne staje się mniej atrakcyjne. Co więcej, instytucje zwiększają możliwości przewidywania zachowań innych państw, „o ile regularnie przestrzegają zasad i standardów instytucji międzynarodowych, sygnalizują chęć kontynuowania wzorców współpracy, a tym samym wzmacniają oczekiwania stabilności” (Hellmann, Wolf, 1993, s. 10). W związku z tym teoria neoliberalnego instytucjonalizmu zakłada, że państwa często rezygnują z części swojej autonomii na rzecz międzynarodowej współpracy. Jak zauważa Arthur Stein: „suwerenne narody mają racjonalną motywację do rozwijania procesów podejmowania wspólnych decyzji w obliczu dylematów powszechnej niechęci. W tych kontekstach egoistyczni aktorzy racjonalnie rezygnują z samodzielnego podejmowania decyzji i konstruują reżimy" (Stein, 1990, s. 54; Hellmann, Wolf, 1993, s. 10).

Owe instytucje można zdefiniować z jednej strony jako wspólne wzorce i praktyki współdziałania, ale również rozwinięte systemy zarządzania międzyrządową współpracą. Instytucje w różnym stopniu korzystają z narzędzi monitorowania i regulowania zachowań państw (Wheeler, 2014). Instytucje te w tym kontekście pełnią kluczową rolę we wzmacnianiu kooperacji, gdyż zwiększają przejrzystość oraz wspólną odpowiedzialność za podejmowane działania, co zmniejsza niepewność dotyczącą motywów i intencji innych państw. Poprzez dostarczanie informacji instytucje wpływają na państwa i ich strategie, gdyż zwiększają prawdopodobieństwo określonych zachowań w poszczególnych sytuacjach. Ponadto instytucje mogą promować współpracę, o ile informacje, jakich dostarczają, kształtują przekonanie, że państwa w długoterminowej współpracy upatrują wspólny interes.

Keohane stwierdzit, że rozwiązania instytucjonalne w znacznym stopniu determinują działania państw. Do kluczowych rozwiązań instytucjonalnych zaliczył: przepływ informacji oraz możliwości negocjacyjne; gotowość rządów do podejmowania i realizacji wiarygodnych zobowiązań i zdolność monitorowania wypełniania zobowiązań przez inne państwa; powszechna zgoda co do trwałości międzynarodowych umów (Keohane, 2011, s. 157-164). Zdolność państw do komunikowa- 
nia się i współpracy zarówno minilateralnej, jak i multilateralnej w dużym stopniu zależna jest od instytucji. Jednak perspektywa teoretyczna neoliberalnego instytucjonalizmu jest istotna dla analizy systemu międzynarodowego i relacji w wymiarze globalnym, jeśli dotyczy dwóch czynników. Po pierwsze, państwa muszą mieć wspólne interesy, co oznacza, że muszą czerpać korzyści z kooperacji. Po drugie, różnice instytucjonalne wpływają na różnice w zachowaniach państw. W związku z tym Keohane definiuje instytucje jako „trwałe, połączone zestawy reguł formalnych i nieformalnych, które określają zachowania i odgrywane role, ograniczają aktywność i kształtują oczekiwania” (Keohane, 2011, s. 157-164). Instytucje mogą tym samym przybierać określone formy: formalnych międzyrządowych lub ponadnarodowych organizacji pozarządowych; międzynarodowych reżimów; zwyczajowych praktyk. Instytucje międzynarodowe umożliwiają państwom ustanawianie inicjatyw i podejmowanie działań, które nie byłyby możliwe do przeprowadzenia w ramach indywidualnych zdolności. Pomagają również niwelować koszty alternatywne, które występują przy działaniach niezależnych. Wpływają na zrozumienie roli, jaką powinni odgrywać przywódcy państw, uwzględniając przy tym nie tylko motywację innych i własne interesy, ale również pozytywne skutki trwałej współpracy międzynarodowej. Jak wskazują założenia neoliberalnego instytucjonalizmu, aktorzy tworzą instytucje $\mathrm{w}$ anarchicznym systemie międzynarodowym, aby zwiększyć przejrzystość działań i zwiększyć efektywność współpracy, która uzależniona jest od interesów i motywów, ale także od liczby stron. Jak argumentuje Maximilian Hohenstedt, w stosunkach międzynarodowych sprzeczne interesy oraz sytuacje o zróżnicowanych motywach utrudniają współpracę, natomiast wspólne interesy sprzyjają długoterminowym strategiom kooperacyjnym (Hohenstedt, 2017, s. 2-10). Ponadto współpracy ma sprzyjać ograniczenie liczby stron. Zgodnie z tymi twierdzeniami, aby przezwyciężyć antagonizm, państwa muszą stworzyć (czy też powiększyć) „cień przyszłości” na podstawie wspólnych interesów i zredukować liczbę aktorów (Axelrod, 1984, s. 124-126). Jest to możliwe dzięki instytucjom, takim jak organizacje międzynarodowe, które zmieniają liczbę stron, tworzą procedury i zasady współdziałania oparte na wspólnych interesach. W ramach organizacji istnieje możliwość tworzenia formatów ograniczonych do określonej liczby państw, związanych wspólnotą interesów w określonych obszarach. Jak zauważa Keohane, sukcesywnie malejąca nieufność sprzyja funkcjonowaniu także długoterminowych relacji kooperacyjnych z asymetrycznym rozkładem zysków (Keohane, 1990, s. 744-752). Państwa mogą legitymizować wyższą pozycję lidera, o ile jego działania są przejrzyste i służą wspólnym interesom.

Złożoność stosunków międzynarodowych, rozwinięte sieci współzależności gospodarczej i politycznej oraz skala i charakter problemów, z jakimi muszą mierzyć 
się państwa we współczesnym świecie, nie pozwalają na skuteczne działanie w pojedynkę i zmuszają do współpracy z innymi podmiotami. Instytucje międzynarodowe, które obniżają koszty transakcyjne w interakcjach między państwami, ,jeśli są zinstytucjonalizowane w bardziej formalny sposób, zapewniają fora, które mogą działać jako katalizatory porozumienia, umożliwiając tym samym rządom wykorzystanie potencjalnych korzyści skali” (Hellmann, Wolf, 1993, s. 16-17). Co więcej, państwa muszą uwzględniać możliwość nałożenia sankcji za odstąpienie od warunków porozumienia, które doprowadziło do powstania owych instytucji (Hellmann, Wolf, 1993, s. 17-18). Jest to twierdzenie szczególnie trafne, jeśli instytucje łączą państwa, które są od siebie współzależne w wielu obszarach. Instytucjonalizacja współpracy zwiększa szanse na respektowanie wspólnych zobowiązań i wzmacnia zachowania kooperatywne.

Perspektywa neoliberalnego instytucjonalizmu jest użyteczna w kontekście analizy relacji międzynarodowych i przywództwa kooperatywnego, gdyż wyjaśnia zachowania państw zarówno na płaszczyźnie interesów narodowych, jak i interakcji. Jednym z kluczowych założeń tej teorii jest zjawisko, które teoretycy koncepcji współpracy określają jako długi „cień przyszłości” (shadow of the future). Zgodnie z nim uczestnicy stosunków międzynarodowych będą koncentrować się na długiej perspektywie współpracy, opartej na wspólnych interesach. Określanie korzyści i zysków w perspektywie krótkookresowej nie jest efektywne, gdyż jak twierdzą neoliberalni instytucjonaliści - prowadzi do długookresowych strat w przypadku, gdy podmioty zdecydowałyby się na współdziałanie w przyszłości. Zatem w odróżnieniu od podejścia neorealistycznego trwałe formy współpracy są możliwe, a nawet konieczne w warunkach międzynarodowej anarchii. Innymi słowy, możliwe jest „globalne zarządzanie nawet przy braku globalnego rządu” (Wheeler, 2014).

\section{Przywództwo indywidualne a przywództwo kooperatywne}

Rozważając zagadnienie przywództwa w UE, należy uwzględnić rozwiązania instytucjonalno-traktatowe, zgodnie z którymi „Unia szanuje równość Państw Członkowskich wobec Traktatów [...]” (art. 4 TUE). Takie postanowienia wykluczają różnicowanie pozycji i statusu państw członkowskich. Mimo przyjętych podstaw prawnych rola Niemiec jako nieformalnego lidera Wspólnoty staje się coraz częściej przedmiotem politycznej debaty o UE. Z kolei wybór Emmanuela Macrona na prezydenta Francji rozpoczął dyskusje na temat francuskich ambicji integracyjnych. Badania dotyczące prób mierzenia potęgi i wyjaśnienia pozycji Niemiec opierały się często na definiowaniu jej w kategoriach hegemonii i dominacji gospo- 
darczej. Uwzględniając z kolei założenia neoliberalnego instytucjonalizmu związane zarówno z rolą państw, jak i instytucji zapewniających przejrzystość działań, a także biorąc pod uwagę długotrwałe korzyści ze współpracy, za bardziej uzasadnione należy uznać traktowanie zagadnienia przywództwa w kontekście zachowań kooperacyjnych. Biorąc pod uwagę możliwość poddania analizie przywództwa kooperatywnego, należy wskazać ustęp 3 art. 4 TUE, który stanowi, że „Zgodnie z zasadą lojalnej współpracy Unia i Państwa Członkowskie wzajemnie się szanują i udzielają sobie wzajemnego wsparcia w wykonywaniu zadań wynikających z Traktatów”. W tym ujęciu przywództwo Niemiec w UE należy postrzegać jako proces, w trakcie którego państwo stara się wpływać na grupę innych państw, zarządzać jej działaniami w kierunku wspólnych decyzji, wspólnych celów i satysfakcjonujących wyników (Avery, 2004, s. 22). Odpowiedzialność za rozwój systemu instytucji spoczywa nie na jednym podmiocie w roli lidera, ale na wszystkich podmiotach je tworzących. Lider (leader) wskazuje natomiast kierunek działań, dzieli obowiązki i ułatwia realizację wspólnych celów. Pozostałe państwa w roli „podążających” (followers) współtworzą agendę i akceptują rolę lidera. Aby przywództwo kooperatywne było skuteczne musi jednak opierać się na spójnych działaniach, konsensusie co do przyjętych narzędzi realizacji celów oraz uzyskać akceptację wszystkich współpracujących ze sobą podmiotów (García, 2007; Clark, 2005).

Procesy zależności, na jakich opiera się funkcjonowanie ponadnarodowych i międzyrządowych struktur UE, w sposób bardzo trafny zostały wyjaśnione za pomocą metafory zachowania migracyjnego „stada latających ptaków”, która została zaproponowana przez Henry'ego i Williama Wallace'ów w opracowaniu dotyczącym procesów unijnych zorientowanych na walkę sił integracji i sił fragmentacji. Stado wspomnianych ptaków leci w określonym szyku, funkcjonalnym pod względem aerodynamicznym i behawioralnym. Formacja skonfigurowana jest w taki sposób, aby zapewniać siłę nośną i utrzymywać prędkość na długich dystansach, a także w miarę możliwości zmniejszać wpływ turbulencji na zachwiania równowagi całego stada, gdyż wytrącenie z szyku jednego ptaka może zaburzyć lot całej formacji. Posługując się symboliczną terminologią, eksperci podkreślili, że silniejsze lub dominujące ptaki odpowiadają za sygnalizowanie innym kierunku lotu (Wallace, Wallace, 1995, s. 28). Na uwagę zasługuje fakt, że ptaki zmieniają pozycje w szyku, aby zróżnicować obowiązki całej grupy i ochronić zmęczonych członków stada. Zatem atrakcyjność takiej metafory polega na tym, iż pozwala ona na uwzględnienie zmiennej liczby członków grupy i powtarzalne zmiany w przywództwie, a także podzbiorów członków o bliższej tożsamości grupowej, które jednak pozostają zależne od procesu zbiorowego oraz kolektywnych zasad rządzących ich zachowaniem. UE składa się z podmiotów o zróżnicowanych interesach, odmien- 
nych celach i innych preferencjach w zakresie tempa i postępów integracyjnych. Realizacja spójnej polityki jest zatem utrudniona, a trudność ta polega na tym, że „nie wszystkie ptaki są jednym gatunkiem, niektóre z nich mogą być orłami, inne wróblami, a niektóre mogą być kurczętami, które nie potrafią latać" (Wallace, Wallace, 1995, s. 27-28). Metafora ta jest użyteczna w kontekście analizy polityczności w UE, gdyż nawiązuje do wizji ,jedności w różnorodności”, którą kieruję się Wspólnota w kontekście projektu zjednoczonej Europy - projektu, który szczególnie w przypadku kryzysów (wspomnianych turbulencji, które zakłócają podróż) potrzebuje siły napędowej - lidera, który wskaże kierunek. Jest również użyteczna w badaniu determinantów sojuszu niemiecko-francuskiego oraz jego wpływu na wdrażanie w ramach UE inicjatyw, które stają się częścią wspólnotowych polityk.

Neoliberalny instytucjonalizm, który przypisuje duże znaczenie zarówno instytucjom, regulacjom i procedurom występującym na poziomie sformalizowanych struktur współpracy w ramach UE, jak i państwom jako kluczowym podmiotom tejże współpracy, pomaga wyjaśnić fenomen specyfiki instytucjonalnej UE, która łączy zarówno ponadnarodowe, jak i międzyrządowe mechanizmy wdrażania polityk. Z drugiej strony państwo narodowe pozostaje kluczowym podmiotem kształtowania międzynarodowych relacji, a jego wpływ uzależniony jest od siły oddziaływania na instytucje, co w dużej mierze w przypadku UE warunkowane jest potencjałem budowania trwałych koalicji. Współpraca w ramach mniejszych formatów stała się ważnym elementem polityki zagranicznej UE. Taką formę współpracy preferują szczególnie Niemcy. Jako państwo o kluczowym potencjale gospodarczym biorą odpowiedzialność za przewodzenie Wspólnocie w kontaktach międzynarodowych, ale jednocześnie nie chcą realizować celów samodzielnie czy poza ramami UE.

Taką perspektywę określania pozycji i wpływu państwa w UE potwierdził raport przygotowany przez ekspertów z zakresu polityki europejskiej dla Polskiej Fundacji im. Roberta Schumana oraz Fundacji Konrada Adenauera. Raport został opublikowany w maju 2020 r. i przedstawiał wyniki badań rankingowych dotyczących siły oddziaływania poszczególnych państw członkowskich na forum UE. Wpływ państw był mierzony na podstawie kilku wskaźników: siły głosu w instytucjach unijnych, przede wszystkim w Radzie UE i Parlamencie Europejskim; wizerunku i reputacji danego państwa oraz zdolności do budowania trwałych koalicji w ramach UE, które są ważne w aspekcie wypracowania wspólnych rozwiązań i skutecznej realizacji działań w niektórych obszarach. Dokładna analiza tych wskaźników pozwoliła na uszeregowanie państw pod względem siły ich oddziaływania. Zgodnie z wynikami badań rankingowych trzema najbardziej wpływowymi państwami są kolejno: Niemcy, później Francja, a następnie Włochy (Sus 
i Wiejski, 2020, s. 9-21). Siła głosu w Radzie i Parlamencie obliczana jest na podstawie postanowień traktatowych zawartych w art. 14(2) i art. 16(4) TUE; art. 294 TFUE. Rada UE jako główna instytucja procedury podejmowania decyzji w zależności od rodzaju spraw będących przedmiotem debaty może uruchomić procedurę głosowania zwykłego (aby decyzja została podjęta, głosów „za” musi oddać co najmniej 14 państw członkowskich); głosowania jednogłośnego (wszystkie państwa muszą zagłosować „za”) lub głosowania kwalifikowanego. Zgodnie z przyjętym mechanizmem taka większość oznacza, że „za” musi zagłosować 55\% państw członkowskich reprezentujących co najmniej $65 \%$ ludności UE. W tym przypadku najbardziej uprzywilejowane są państwa największe pod względem powierzchni oraz liczby ludności. Nawet największe państwo nie może jednak wpływać samodzielnie na kształtowanie procesu decyzyjnego. W związku z tym o sile i pozycji państwa decyduje również współczynnik koalicyjności oraz jego reputacja i wizerunek, szczególnie postrzeganie roli danego państwa przez innych członków.

Zdolność tworzenia koalicji została zmierzona w rankingu za pomocą obserwacji pośredniej wyników głosowań w Radzie UE od 2015 r. Zbadano, z którymi państwami pozostali członkowie Wspólnoty głosowali tak samo. Po analizie wynik uśredniono, uwzględniając przy tym wskaźnik siły głosu koalicjantów. Jak wykazały badania, pod względem siły głosu pierwsze miejsce zajęły Niemcy, a drugie Francja. Pod względem skuteczności budowania koalicji Niemcy zajęły drugie miejsce, zaraz po Francji. Warto przy tym zauważyć, że najczęściej te państwa głosowały tak samo, jednak nawet ich silny sojusz z potencjałem przewodzenia UE potrzebuje rozwoju współpracy z innymi państwami członkowskimi. Państwa te muszą być postrzegane jako atrakcyjni koalicjanci, którzy włączają inne państwa w formaty minilateralne (Sus, Wiejski, 2020, s. 10-20). Z jednej strony rozwiązania traktatowe dają formalne podstawy zwiększenia siły głosu państw takich jak Niemcy. $\mathrm{Z}$ drugiej strony współpraca i zdolność do tworzenia koalicji pozostają równie ważne w aspekcie politycznego oddziaływania.

Wpływ Niemiec w UE potwierdza również sondaż Coalition Explorer przeprowadzony przez Europejską Radę Spraw Zagranicznych (European Council on Foreign Relations - ECFR) w ramach trzeciej edycji badań ankietowych wśród ekspertów zajmujących się polityką europejską (urzędników, dziennikarzy, analityków, naukowców etc.). Badania przeprowadzane są wśród respondentów wszystkich państw członkowskich, zatem przedstawiają zróżnicowane opinie. Sondaż pokazuje potencjał przyszłych koalicji budowanych przez państwa członkowskie UE w ramach różnych obszarów polityk, a także lokalizuje polityczne centra, które mogą stać się szansą na bardziej spójne i zintegrowane działania. W ostatnim badaniu przeprowadzonym między 11 marca a 28 kwietnia 2020 r. przeanalizowa- 
no potencjał Francji i Niemiec dotyczący wspólnego przewodzenia UE w sprawach zagranicznych. Wyniki badań ankietowych, opublikowane w lipcu 2020 r., potwierdzają zgodną opinię ekspertów co do znaczenia i wpływu współpracy Niemiec i Francji. W badaniach wskazano na kluczową rolę tych dwóch państw, określając zakres, w jakim postrzegane są przez inne państwa członkowskie jako liderzy Wspólnoty. Analiza diagnozuje również stan relacji roboczych między tymi dwoma państwami oraz określa, w jakim stopniu mogą wykorzystać swój indywidualny i połączony potencjał, aby zwiększyć spójność Wspólnej Polityki Zagranicznej i Bezpieczeństwa. Do przeprowadzenia badania przygotowano anonimowy kwestionariusz internetowy, który został rozesłany przez Europejską Radę Spraw Zagranicznych pocztą elektroniczną do biur rządowych i parlamentów, ministerstw spraw zagranicznych, instytutów badawczych i analitycznych, dziennikarzy oraz innych organizacji, których działacze zajmują się sprawami europejskimi. W ostatniej edycji badań z 2020 r. odpowiedzi udzieliło 845 ekspertów (od 15 do 51 respondentów z każdego państwa członkowskiego).

Pierwsza edycja badań Coalition Explorer została przeprowadzona w 2016 r. i od tego czasu potwierdza się powszechne przekonanie o roli Niemiec jako najbardziej wpływowym państwie członkowskim. W badaniach z 2020 r. ten pogląd podzieliło aż $97 \%$ respondentów; $55 \%$ ekspertów z zakresu spraw europejskich uważa, że to państwo jest najbardziej responsywne i najłatwiej się z nim współpracuje. W odpowiedzi na pytanie: „Z którym z państw członkowskich rząd twojego kraju najczęściej konsultuje się w sprawach dotyczących polityki europejskiej?”, 82\% respondentów wskazało na Niemcy. Co więcej, pomimo wielu sprzeczności wewnątrz UE, 44\% respondentów wskazało, że Niemcy są państwem, które w największym stopniu podziela interesy i priorytety ich państw w zakresie polityki europejskiej, co ulokowało je na pierwszym miejscu również pod względem wspólnych interesów (Puglierin, Franke, Coalition Explorer, 2020). Oznacza to, że Niemcy stanowią polityczne centrum sieci powiązań, relacji i sojuszy tworzonych w ramach UE.

Wyniki badań ankietowych są zbieżne ze stanowiskiem niemieckich decydentów w sprawie definiowania roli w UE państwa niemieckiego, które nie chce być hegemonem narzucającym własną wolę polityczną pozostałym państwom członkowskim, ale pretenduje do roli lidera wspomagającego koordynację wspólnych działań. Jak zapowiedział Heiko Maas, minister spraw zagranicznych RFN, uchwalając program niemieckiej prezydencji w Radzie UE, Niemcy będą „siłą napędową i moderatorem podczas swojej prezydencji w Radzie UE. Zadaniem naszego państwa będzie budowanie mostów i znajdowanie rozwiązań, które ostatecznie przyniosą korzyści wszystkim w Europie" (auswertiges-amt.de). Co więcej, wyniki badań ankietowych przeprowadzonych wśród niemieckich respondentów wskazują 
na zgodne stanowisko w zakresie podejmowania decyzji w UE. Respondenci z Niemiec opowiedzieli się za konsensusem między wszystkimi państwami członkowskimi jako kluczową metodą podejmowania decyzji. Podkreślili również znaczenie współpracy wszystkich państw członkowskich, a nie tylko wybranych, gdyż taka praktyka mogłaby ich zdaniem osłabić i podzielić UE (Puglierin, Franke, Coalition Explorer, 2020). Niemieccy eksperci akcentowali także zdecydowaną niechęć do współpracy poza ramami UE w którymkolwiek z obszarów polityki objętych badaniem, co potwierdza założenia neoliberalnego instytucjonalizmu, dotyczące znaczenia procedur i instytucji, które wzmacniają przejrzystość i skuteczność współpracy. Istnienie wielu mechanizmów i rozwiązań przyjętych na poziomie UE pozwala Niemcom, jako najbardziej wpływowemu państwu, koordynować działania i realizować wspólne interesy w oparciu o ogólnie obowiązujące standardy.

Drugie miejsce w sondażu zajęła Francja. Jest to najbliższy sojusznik i kluczowy koalicjant Niemiec, z którym najczęściej konsultowały się w sprawach dotyczących polityki europejskiej. Aż 93\% (o 4\% mniej niż w przypadku Niemiec) respondentów potwierdziło, że jest to najbardziej wpływowe państwo, a aż 78\% respondentów (o 7\% więcej niż w przypadku Niemiec) stwierdziło, że jest to państwo najbardziej oddane projektowi pogłębiania integracji europejskiej. Francja nie jest natomiast postrzegana jako państwo kluczowe pod względem konsultowania się z nim w sprawach dotyczących polityki europejskiej (50\%). Ponadto tylko 27\% respondentów postrzega ją jako państwo responsywne i zdolne do współpracy. Francja nie jest zatem postrzegana jako kluczowy koalicjant dla większości państw europejskich i zgodnie z wynikami badań, mimo że jest wpływowym i ważnym państwem, nie może być liderem Wspólnoty. Pozostaje natomiast kluczowym partnerem Niemiec, a potencjał ich wspólnego przewodzenia może mieć znaczący wpływ na kształtowanie polityk UE. Na kolejnych miejscach znajduje się Holandia (55\%), Włochy (37\%) i Hiszpania (33\%) (Puglierin, Franke, Coalition Explorer, 2020).

Różnice w postrzeganiu wpływu i znaczenia poszczególnych państw (w zakresie konsultowania się w sprawach związanych z polityką europejską oraz łatwości we współpracy z rządami tych państw) uzależnione są również od regionu, w którym badania były prowadzone. Jak wynika z badań, respondenci francuscy dostrzegają mniej wspólnych interesów z krajami Europy Wschodniej, przez co współpraca tego państwa koncentruje się szczególnie na wymiarze północnym i południowym. Pozycja Francji jest zdecydowanie silniejsza wśród respondentów z Europy Południowej, którzy oceniają ją jako jeden z krajów, z którym kontaktują się najczęściej w sprawach związanych z UE i z którym chętnie współpracują. W Grecji, Portugalii, na Cyprze i w Hiszpanii co najmniej 80\% respondentów uważa, że współpra- 
ca z Francją jest łatwa, a Włochy, Grecja i Cypr postrzegają Francję jako najważniejszego rozmówcę. Z kolei respondenci z Litwy, Łotwy, Polski, Czech i Węgier uznają Francję za mało responsywną i mało otwartą na współpracę. Niemcy najczęściej kontaktują się w sprawach związanych z polityką europejską z Francją, Austrią, Holandią, ale również Hiszpanią, Polską i Włochami. Polska oraz inne kraje Europy Środkowej i Wschodniej nadal pozostają ważnymi partnerami Niemiec, co przekłada się na zaangażowanie tego państwa we włączanie ich do aktywnego tworzenia unijnej agendy. Widać to także w wynikach dotyczących wspólnych interesów - aż 44\% respondentów stwierdziło bowiem, że Niemcy podzielają interesy ich państw w sprawach polityki europejskiej (Puglierin, Franke, Coalition Explorer, 2020).

\section{Działania kooperatywne w ramach Wspólnej Polityki Zagranicznej i Bezpieczeństwa}

Jednym z obszarów polityk, w którym kooperacja państw członkowskich została formalnie zagwarantowana poprzez wprowadzenie rozwiązań instytucjonalno-prawnych dla uzyskania długookresowych korzyści zarówno przez same państwa, jak i całą UE, jest Wspólna Polityka Zagraniczna i Bezpieczeństwa, która określa instrumentarium do podejmowania działań zewnętrznych. Analiza ewolucji historycznej tejże polityki wspólnotowej nie jest przedmiotem artykułu, dlatego uwaga została skoncentrowana na wybranych jej aspektach, na podstawie których można zaobserwować adaptację określonych instrumentów WPZiB przez państwa członkowskie podejmujące działania w wymiarze globalnym, służąc jednocześnie interesom całej UE. Państwa pomimo swojego politycznego potencjału nie działają przy tym samodzielnie, ale kierują się zasadą umacniania systematycznej współpracy (art. 25 TUE), włączając w swoje działania wybrane państwa i kierując wspólnymi inicjatywami. Ma tutaj zastosowanie model przywództwa kooperatywnego, w którym rolę lidera przyjmuje państwo o dużym potencjale politycznym i ekonomicznym, postrzegane w wymiarze globalnym jako znaczący partner.

Zgodnie z postanowieniami zawartymi w art. 25 TUE, Unia realizuje WPZiB poprzez: określanie ogólnych wytycznych tej polityki; podejmowanie decyzji określających działania, jakie powinny być prowadzone przez UE (przed Traktatem z Lizbony tzw. wspólne działania); stanowiska, jakie powinny zostać przyjęte przez UE (przed Traktatem z Lizbony tzw. wspólne stanowiska) oraz zasady wykonania tych decyzji; a także poprzez umacnianie systematycznej współpracy między państwami członkowskimi. W przypadku WPZiB kluczową rolę odgrywają in- 
stytucje o charakterze międzyrządowym. Rada Europejska, która składa się z szefów państw lub szefów rządów państw członkowskich, przyjmuje ogólne wytyczne dotyczące rozwoju UE, w tym kierunki rozwoju działalności dyplomatycznej. $\mathrm{Na}$ podstawie ogólnych wytycznych Rady Europejskiej Rada UE podejmuje decyzje w zakresie określania i implementowania WPZiB (art. 26 ust. 2 TUE). Decyduje także o wprowadzeniu w życie decyzji określających aktywności, jakie powinny być prowadzone przez UE w razie konieczności podjęcia działań operacyjnych. Wówczas Rada UE określa czas, warunki i zasięg tych działań oraz środki i narzędzia ich realizacji. Państwa członkowskie muszą natomiast uwzględniać te decyzje przy określaniu strategii polityki zagranicznej (art. 28 ust. 2 TUE). Ponadto muszą informować na forum Rady o działaniach, jakie podejmują w zakresie wspólnych działań UE, a w przypadku, gdy sytuacja, co do której wspólne działania zostały ustalone, uwzględniać także zmiany wprowadzone przez Radę w celu rewizji środków i celów działania (art. 28 ust. 1 TUE). Jeśli na poziomie UE nie zostały jeszcze ustalone ramy wspólnych działań, a sytuacja wymaga natychmiastowych interwencji, wówczas państwo członkowskie, uwzględniając zasadę wspólnego podejścia UE do danej kwestii, może podjąć samodzielne działania, informując o tym Radę UE (art. 28 ust. 4 TUE). Rozwiązania instytucjonalne WPZiB dostarczają zatem, zgodnie z założeniami neoliberalnego instytucjonalizmu, informacji na temat działań państw i zwiększają ich przejrzystość. Tym samym wykluczają działania zorientowane na egoistyczną realizację wyłącznych interesów państwa. Taki model instytucjonalny nie sprzyja zachowaniom indywidualnym i samodzielnym, a lider odgrywa rolę koordynatora wspólnych działań.

Zgodnie z postanowieniami traktatowymi Rada UE w ramach WPZiB podejmuje również decyzje, które określają stanowiska, tzn. wspólne podejście UE do problemów o charakterze geograficznym lub przedmiotowym. Państwa członkowskie są zobowiązane do zapewnienia zgodności własnych polityk ze stanowiskami UE, a także wspierania tych stanowisk na forach organizacji międzynarodowych (art. 29 TUE). Ponadto Francja jako stały członek Rady Bezpieczeństwa ONZ zobowiązana jest do funkcjonowania w ramach tego organu zgodnie $\mathrm{z}$ interesami UE, szczególnie gdy agenda obrad obejmuje kwestie będące przedmiotem wspólnego stanowiska UE. Państwa członkowskie, działając na forum organizacji w zakresie spraw, które mogłyby wpłynąć na interesy UE, powinny mieć na uwadze dobro Unii i informować pozostałe państwa członkowskie na forum instytucji o tych działaniach i konsultować je z pozostałymi członkami, co również jest rozwiązaniem sprzyjającym transparentności i ograniczaniu działań na szkodę innych państw członkowskich (art. 32 TUE). Placówki dyplomatyczne państw członkowskich, a także delegatury UE i jej przedstawicielstwa w państwach trzecich i przy 
organizacjach międzynarodowych powinny tworzyć sieć współpracy w zakresie wymiany informacji i analizy sytuacji w taki sposób, aby zapewnić skuteczne wykonywanie decyzji określających wspólne stanowiska i działania (art. 35 TUE).

Zgodnie z zasadą umacniania systematycznej współpracy państwa członkowskie, podejmując działania w ramach polityki zagranicznej, powinny powstrzymywać się od zobowiązań, które mogłyby szkodzić interesom UE i zagrozić spójności WPZiB. Konsultacje na forum Rady mają sprzyjać zarówno dostarczaniu informacji i uzgadnianiu kwestii polityki zagranicznej i bezpieczeństwa, jak i maksymalizować wpływ Unii na bieżące wydarzenia. Ponadto, zgodnie z art. 42 TUE, państwa członkowskie, które spełniają wyższe kryteria zdolności wojskowej, mogą ustanowić mechanizm stałej współpracy strukturalnej w celu pogłębiania integracji w tej dziedzinie. Państwa członkowskie skorzystały z tej możliwości w 2017 r., ustanawiając PESCO (Permanent Structured Cooperation). Jej inicjatorami stały się Francja i Niemcy, które przewodzą największej liczbie projektów realizowanych w jej ramach.

Niemcy to państwo, które odgrywa czołową rolę w działaniach zewnętrznych UE. Potencjał politycznej odpowiedzialności za wspólne interesy Unii opiera się przede wszystkim na modelu dyplomatycznego zaangażowania na kontynencie europejskim i poza nim (Helwig, 2020, s. 25-41; Zawadzka, 2020, s. 96-97). Niemcy wdrażają jednocześnie podejście kooperatywne i nie angażują się w coraz bardziej napiętą rywalizację geopolityczną, mając na uwadze długookresowe korzyści polityczne i gospodarcze wynikające ze współpracy. Uwzględniają mechanizmy instytucjonalne WPZiB, które zobowiązują państwa członkowskie do dostarczania instytucjom UE informacji na temat działań mających wpływ na jej interesy. Było to szczególnie widoczne $\mathrm{w}$ trakcie prowadzonych negocjacji międzynarodowych, kiedy Niemcy wraz z innymi państwami członkowskimi po wypracowaniu spójnego stanowiska UE przedstawiały je na forum międzynarodowym, jednocześnie konsultując kolejne etapy negocjacji z pozostałymi państwami członkowskimi na forum instytucji. Takie podejście w kontekście zarządzania kryzysowego można było zaobserwować już w ramach działań Bałkańskiej Grupy Kontaktowej, która od 1994 r. stanowiła forum koordynacji wspólnych wysiłków Stanów Zjednoczonych, Federacji Rosyjskiej, Francji, Wielkiej Brytanii, Niemiec i Włoch w negocjowaniu porozumień pokojowych dla Bośni i Hercegowiny; negocjacji w sprawie irańskiego programu jądrowego w ramach formatu E3+3, w które zaangażowane były trzy państwa członkowskie UE (Francja, Niemcy i Wielka Brytania), współpracujące z Wysokim Przedstawicielem UE, czy mediacje formatu normandzkiego podczas kryzysu na Ukrainie, w które zaangażowały się Niemcy i Francja, reprezentując spójne stanowisko UE. 
Analiza wszystkich wskazanych przykładów nie jest konieczna do wyjaśnienia determinantów przywództwa kooperatywnego Niemiec, dlatego uwaga zostanie skoncentrowana na jednym studium przypadku: mediacji na rzecz deeskalacji kryzysu na Ukrainie, który rozpoczął się, kiedy prezydent Ukrainy Wiktor Janukowycz w 2013 r. odmówił podpisania umowy stowarzyszeniowej z UE. Sytuacja doprowadziła do wybuchu zamieszek, w których udział wzięli proeuropejscy demonstranci. UE traktowana była, szczególnie przez Federację Rosyjską, jako strona konfliktu, która nie powinna bezpośrednio angażować się w mediacje (Helwig, 2020, s. 25-41; Zawadzka, 2020, s. 96-97). Początkowo w rozmowy na temat stabilizacji sytuacji na Ukrainie włączyły się państwa zrzeszone w ramach Trójkąta Weimarskiego. Ich działania doprowadziły do zawarcia porozumienia między prezydentem Janukowyczem a przedstawicielami opozycji. W 2014 r. nastąpiła jednak eskalacja konfliktu na Ukrainie, a mediacje objęły kluczowego gracza - Federację Rosyjską. Negocjacje były odtąd prowadzone w ramach formatu normandzkiego, a największą odpowiedzialność za zaangażowanie ze strony państw członkowskich UE przyjęły Niemcy i Francja, które starały się wypracować porozumienie korzystne z perspektywy priorytetów WPZiB. Federica Mogherini jako Przedstawiciel UE wyraziła poparcie dla formatu normandzkiego ze strony Unii, jednak bez formalnego zaangażowania przedstawicieli unijnych instytucji w te negocjacje (Mogherini, 2017), co wzmocniło znaczenie Niemiec i Francji jako liderów dyplomacji europejskiej. Szczególne zadanie przypadło Niemcom, które postrzegane były jako kluczowy partner zarówno przez Ukrainę, jak i Rosję ze względu na potencjał gospodarczy i polityczny w UE oraz rolę, jaką odgrywają w unijnej polityce sankcyjnej. Również Stany Zjednoczone, które zgodnie ze strategią odgrywania w tym konflikcie drugorzędnej roli traktowały rozmowy między rządem Niemiec i Rosji (ze względu na pozycję tych państw na arenie międzynarodowej) jako główną oś mediacji (Packer, 2014; Helwig, 2020, s. 25-41; Zawadzka, 2020, s. 96-97). Zaangażowanie ze strony państw UE doprowadziło do podpisania w 2015 r. drugiego porozumienia mińskiego, którego podstawą były postanowienia o zawieszeniu broni i wycofaniu sprzętu wojskowego z linii walk. Do sukcesu przyczyniły się zabiegi dyplomatyczne kanclerz Angeli Merkel, która kierując się podejściem zarządzania kooperacyjnego, na tydzień przed szczytem w Mińsku odbyła wizyty zagraniczne w Waszyngtonie, Ottawie, Mińsku, Moskwie i Kijowie. Jednocześnie prowadziła stałe telefoniczne konsultacje z prezydentem USA, Francji, Rosji i Ukrainy, aby jeszcze przed spotkaniem w Mińsku wypracować podstawy nowego porozumienia (Księżniakiewicz, 2015, s. 4-5).

Zgodnie z postanowieniami traktatowymi dotyczącymi WPZiB oraz wspólnych interesów UE rząd Niemiec zobowiązał się do ścisłej współpracy z instytu- 
cjami unijnymi i innymi państwami członkowskimi. Na forum Rady UE oraz Rady Europejskiej przedstawiał szczegółowe informacje na temat przebiegu i postępów kolejnych etapów negocjacyjnych w celu wypracowania wspólnego podejścia oraz jednolitej strategii Europy wobec działań Rosji. Instytucje UE nie były bezpośrednio zaangażowane w proces negocjacyjny, dlatego dyplomacją europejską oraz koordynacją spójnego stanowiska kierowały Niemcy przy współpracy z Francją i po ustaleniach wypracowanych z innymi państwami i władzami UE na szczytach Rady Europejskiej i posiedzeniach Rady UE (Natorski, Pomorska, 2016, s. 54-70; Zawadzka, 2020, s. 96-97). Struktury instytucjonalne stały się forum wymiany informacji i gwarancją przejrzystości procesu negocjacyjnego, a stanowisko reprezentowane przez Niemcy i Francję odpowiadało założeniom WPZiB. Z kolei model kooperacyjny, który wprowadziły Niemcy, stał się podstawą do odgrywania roli lidera w dyplomacji europejskiej i legitymizacji reprezentowania stanowiska całej Unii.

\section{Uwagi końcowe}

Badanie roli Niemiec w UE może być prowadzone z różnych perspektyw teoretycznych i metodologicznych. Wybrane podejście wykorzystujące założenia neoliberalnego instytucjonalizmu do zbadania współpracy międzynarodowej jako głównej determinanty przywództwa w ramach określonych zinstytucjonalizowanych struktur wzajemnych powiązań jest jednym z wielu możliwych ujęć. Neoliberalny instytucjonalizm wnosi nowy wkład w rozwój problematyki związanej z definiowaniem i wyjaśnianiem koncepcji przywództwa i pozycji państw w zglobalizowanym świecie. Neoliberalni instytucjonaliści, poza uznawaniem kluczowej roli państw jako głównych podmiotów kształtujących relacje międzynarodowe, przypisują duże znaczenie instytucjom zdefiniowanym wcześniej jako „trwałe, połączone zestawy reguł formalnych i nieformalnych, które określają zachowania i odgrywane role, ograniczają aktywność i kształtują oczekiwania”. Struktury instytucjonalne, w ramach których funkcjonują państwa, nie tylko determinują określone działania wynikające z deklarowanej roli, ale również wpływają na oczekiwania innych podmiotów co do podjęcia tychże działań. Informacje, obowiązujące regulacje i normy ustanowione przez instytucje zmniejszają koszty współpracy i jednocześnie zwiększają możliwości przewidywania zachowań państw.

Państwa członkowskie UE funkcjonują w systemie międzyrządowych i ponadnarodowych rozwiązań instytucjonalnych. Członkostwo w UE jest dobrowolne i opiera się na wspólnocie wartości. Państwa, które decydują się przystąpić do 
UE, muszą również zaakceptować zobowiązania wynikające z postanowień traktatowych. Te rozwiązania z jednej strony ograniczają autonomię, a z drugiej strony neutralizują konsekwencje anarchicznej struktury stosunków międzynarodowych. Przepływ informacji, możliwość konsultowania i negocjowania przyszłych działań, zdolność monitorowania wypełniania zobowiązań to główne determinanty, które sprawiają, że przywództwo może być skuteczne, gdy opiera się na podejściu kooperatywnym. Instytucje stają się główną gwarancją długoterminowych korzyści wynikających z kooperacji. Wnioski byłyby z pewnością inne, gdyby zastosowano podejście neorealistów.

Niemcy jako państwo o znaczącym potencjale politycznym i gospodarczym postrzegane są jako lider dyplomacji europejskiej. Wdrażają w swojej strategii zasadę leader-follower. Zgodnie z tym modelem przywódcą jest podmiot, który przewodzi określonej grupie, mediuje między jej członkami, rozdziela obowiązki i stara się wypracować konsensus bez dominacji i narzucania własnej woli. Swoje przywództwo opiera zatem na podejściu kooperatywnym. Działania Niemiec w ramach kształtowania Wspólnej Polityki Zagranicznej i Bezpieczeństwa są przykładem respektowania i implementowania podstawowych narzędzi instytucjonalnych, które zostały ustanowione, aby działać na rzecz wspólnych interesów. Zgodnie z instrumentarium WPZiB państwa członkowskie, realizując strategię polityki zagranicznej, w sprawach istotnych dla UE powinny działać tak, aby osiagać priorytetowe cele WPZiB i nie działać na szkodę UE. Niemcy, przyjmując rolę lidera dyplomacji europejskiej, współpracowały z Francją w czasie negocjacji i jednocześnie konsultowały się z instytucjami UE i innymi państwami członkowskimi w celu wypracowania wspólnego podejścia. Negocjacje na rzecz deeskalacji konfliktu na Ukrainie ukazały zarówno pozycję państw członkowskich, które brały aktywny udział w negocjacjach, jak i rolę instytucji w zakresie przejrzystości działań tych państw.

\section{Bibliografia:}

Auswärtiges Amt. (2020). Foreign Minister Maas on the Cabinet Decision Concerning the National Programme for Germany's Presidency of the Council of the European Union. Pobrane z: https://www.auswaertiges-amt.de/en/newsroom/news/maas-programme-german-eu-presidency/2356954.

Avery, G.C. (2004). Understanding Leadership. London: Sage.

Axelrod, R. (1984). The Evolution of Cooperation. New York: Basic.

Baldwin, D.A. (1993). Neorealism and Neoliberalism: The Contemporary Debate. New York: Columbia University Press.

Clark, I. (2005). Legitimacy in International Society. Oxford: Oxford University Press. 
García, A. (2007). Cooperative Leadership for a Sustainable World. Wasan Project, Integral Education for Global Responsibility. Stuttgart: Breuninger Stiftung.

Grieco, J. (1990). Cooperation among Nations. Europe, America and Non-Tariff Barriers to Trade. Ithaca: Cornell University Press.

Hellmann, G., Wolf, R. (1993). Neorealism, Neoliberal Institutionalism, and the Future of NATO. Security Studies, 3(1), 3-43.

Helwig, N. (2020). Germany in European Diplomacy: Minilateralism as a Tool for Leadership. German Politics, 29, 25-41.

Hohenstedt, M. (2017). The Usefulness of Neoliberal Institutionalism. Establishment of International Organizations. Pobrane z: https://www.grin.com/document/385718.

Kegley, C. (2008). World Politics: Trend and Transformation. Stamford, CT: Cengage Learning EMEA.

Keohane, R. (1984). After Hegemony: Cooperation and Discord in the World Political Economy. Princeton: Princeton University Press.

Keohane, R. (1990). Multilateralism: An Agenda for Research. International Journal, 45(4), 731-764.

Keohane, R. (2011). Neoliberal Institutionalism. W: C.W. Hughes, L.Y. Meng (red.). Security Studies: a Reader (s. 157-164). New York: Routledge.

Keohane, R., Martin, L. (1995). The Promise of Institutional Theory. International Security, 20(1), 39-51.

Keohane, R., Nye, J. (2001). Power and Interdependence. New York: Longman.

Kozub-Karkut, M. (2015). Liberalizm: charakterystyka teorii w świetle założeń A. Moravcsika. W: E. Stadtmüller, Ł. Fijałkowski (red.). Normy, wartości i instytucje we wspótczesnych stosunkach międzynarodowych (s. 71-86). Warszawa: Wydawnictwo Rambler.

Księżniakiewicz, M. (2015). Niechciany partner. Rola Niemiec w rozwiązywaniu konfliktu na Ukrainie. Biuletyn Niemiecki, 57, 1-16.

Mogherini, F. (2017). Speech by Federica Mogherini at the Munich Security Conference. Pobrane z: https://eeas.europa.eu/headquarters/headquarters-homepage_en/20832/ Speech\%20by\%20Federica\%20Mogherini\%20at\%20the\%20Munich\%20Security\%20Conference.

Natorski, M., Pomorska, K. (2016). Trust and Decision-Making in Times of Crisis: The EU's Response to the Events in Ukraine. Journal of Common Market Studies, 55(1), $54-70$.

Packer, G. (2014). The Quiet German. Pobrane z: http://www.newyorker.com/magazine/2014/12/01/quiet-german.

Puglierin, J., Franke, U.E. (2020). The Big Engine that Might: How France and Germany Can Build a Geopolitical Europe - ECFR/332. Pobrane z: https:/ecfr.eu/publication/ the_big_engine_that_might_how_france_and_germany_can_build_a_geopolitica1_el.

Stein, A. (1990). Why Nations Cooperate. Circumstance and Choice in International Relations. Ithaca: Cornell University Press.

Sus, M., Wiejski, P. (2020). Siła państw cztonkowskich Unii Europejskiej. Warszawa: Polska Fundacja im. Roberta Schumana. 
Thomas, W. (2001). The Ethics of Destruction: Norms and Force in International Relations. Ithaca: Cornell University Press.

Wallace, H., Wallace, W. (1995). Flying Together in a Larger and More Diverse European Union. Hague: Wetenschappelijke Raad voor het Regeringsbeleid.

Waltz, K. (1954). Man, the State and War. A Theoretical Analysis. New York: Columbia University Press.

Waltz, K. (1979). Theory of International Politics. Boston: Addison-Wesley.

Waltz, K. (1990). Realist Thought and Neorealist Theory. Journal of International Affairs, 44(1), 21-38.

Wersje skonsolidowane Traktatu o Unii Europejskiej i Traktatu o funkcjonowaniu Unii Europejskiej. (2012). Dziennik Urzędowy Unii Europejskiej, 2012/C 326/01.

Wheeler, N. (2014). Transcript: Theories of International Relations - Liberalism. Pobrane z: https://www.birmingham.ac.uk/Documents/college-social-sciences/government-society/courses/mooc/2014/neo-liberalism.pdf.

Whyte, A. (2020). Neorealism and Neoliberal Institutionalism: Born of the Same Approach?. Pobrane z: https://www.e-ir.info/pdf/22166.

Zawadzka, S. (2020). Przywództwo Niemiec w Unii Europejskiej w świetle teorii ról społecznych oraz wybranych działań minilateralnych. Przeglad Geopolityczny, 34, $80-102$. 